\begin{tabular}{cc|c}
\hline Tar. Bil. Der. & Journal of Agricultural Sciences \\
& $\begin{array}{c}\text { Dergi web sayfası: } \\
\text { www.agri.ankara.edu.tr/dergi }\end{array}$ & Journal homepage: \\
& www.agri.ankara.edu.tr/journal
\end{tabular}

\title{
Some Technological and Functional Properties of Lactic Acid Bacteria Isolated from Hardaliye
}

\author{
Muhammet ARICI ${ }^{a}$, Fatma COSKUN ${ }^{b}$, Gulnaz CELIKYURT ${ }^{c}$, Mustafa MIRIK ${ }^{\mathrm{d}}$, Mehmet GULCU , $^{\mathrm{e}}$ \\ Nazan TOKATLI ${ }^{\mathrm{f}}$ \\ ${ }^{a}$ Yildiz Technical University, Faculty of Chemical and Metallurgical Engineering, Department of Food Engineering, 34210, Istanbul, TURKEY

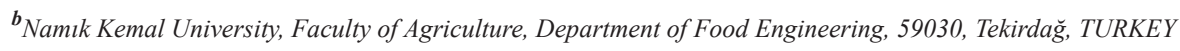 \\ ${ }^{c}$ Balikesir Metropolitan Municipality, 10010 Karesi, Balıkesir, TURKEY

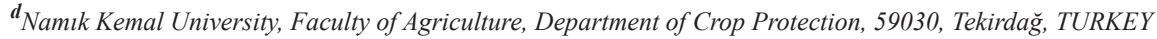 \\ ${ }^{e}$ Directorate of Tekirdağ Viticulture Research Institute, 59100, Tekirdağ, TURKEY

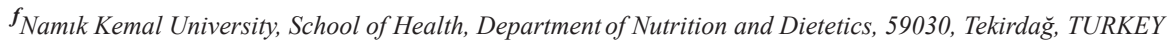

\section{ARTICLE INFO}

Research Article DOI: $10.15832 /$ ankutbd.385870

Corresponding Author: Fatma COSKUN, E-mail: fcoskun@nku.edu.tr, Tel: +90 (282) 2502162

Received: 12 November 2014, Received in Revised Form: 15 April 2016, Accepted: 18 April 2016

\begin{abstract}
Hardaliye is a lactic acid fermented beverage produced from red grape or grape juice with addition of crushed mustard seeds and benzoic acid and it is widely produced and consumed in the Thrace region of Turkey. The aim of this study was to determine the dominant lactic acid bacteria (LAB) species found in hardaliye and to investigate their technological properties related to probiotic action and potential use as a starter culture for production of hardaliye. For this aim; LAB were isolated from 28 hardaliye samples ( 23 hardaliye samples that were obtained from different regions of Kirklareli, Turkey and 5 hardaliye samples were produced by using traditional methods in laboratory conditions). After carrying out conventional and molecular biological methods, it was found that all LAB species isolated belonged to genus Lactobacillus. The dominant species in the microbiota was found to be Lactobacillus plantarum while around $98 \%$ of the isolates were similar to each other. Therefore, it was well understood that a small diversity of LAB strains played role during the fermentation process. The results of this study revealed that the isolates had the potential to be used as starter cultures in hardaliye production due to their antimicrobial effects and acid production capabilities.
\end{abstract}

Keywords: Hardaliye; Lactobacillus; Probiotic properties; Technological properties

\section{Hardaliyeden İzole Edilen Laktik Asit Bakterilerinin Bazı Teknolojik ve Fonksiyonel Özellikleri}

\section{ESER BILGISİ}

Araştırma Makalesi

Sorumlu Yazar: Fatma COSKUN, E-posta: fcoskun@nku.edu.tr, Tel: +90 (282) 2502162

Geliş Tarihi: 12 Kasım 2014, Düzeltmelerin Geliși: 15 Nisan 2016, Kabul: 18 Nisan 2016 


\begin{abstract}
ÖZET
Hardaliye; benzoik asit ve ezilmiş hardal tohumu ilavesiyle kırmızı üzüm ya da üzüm suyundan üretilen laktik asit fermentasyonuna uğramış bir içecektir ve yaygın olarak Türkiye'nin Trakya Bölgesi'nde üretilmekte ve tüketilmektedir. $\mathrm{Bu}$ çalışmanın amacı hardaliyedeki baskın laktik asit bakterisi türlerini belirlemek ve onların teknolojik ve probiyotik özellikleri ile hardaliye üretiminde starter kültür olarak potansiyel kullanımını araştırmaktır. Bu amaçla toplam 28 hardaliye örneğinden (Türkiye'de Kırklareli'nin farklı bölgelerinden toplanan 23 hardaliye örneği ve laboratuvar şartlarında geleneksel yöntemler kullanılarak üretilen 5 hardaliye örneği) laktik asit bakterileri (LAB) izole edilmiş ve tanımlanmıştır. Geleneksel ve moleküler biyolojik yöntemler uygulandıktan sonra, tüm LAB türlerinin Lactobacillus cinsine ait olduğu bulunmuştur. İzolatların yaklaşık \% 98'i birbirine benzerken mikrobiyotadaki baskın tür Lactobacillus plantarum olarak bulunmuştur. Bundan dolayı, fermentasyon sırasında etkili LAB çeşitliliğinin düşük olduğu anlaşılmıştır. LAB'nin antimikrobiyal etkileri ve asit üretim yetenekleri göz önünde bulundurulduğunda, bu çalışmanın sonuçları izolatların hardaliye üretiminde kullanılmak için starter kültür olarak potansiyele sahip olduklarını göstermiştir. Anahtar Kelimeler: Hardaliye; Lactobacillus; Probiyotik özellikler; Teknolojik özellikler
\end{abstract}

(C) Ankara Üniversitesi Ziraat Fakültesi

\section{Introduction}

Lactic acid bacteria (LAB) are the main technological group of microorganisms that are responsible for the production of fermented products with a great economic importance.

Fermentation is one of the oldest methods for increasing the shelf life of food products (Battock \& Azam-Ali 1998). Today, LAB have attracted attention of researches due to their essential role in most fermented foods and their abilities to produce various antimicrobial compounds as well as their probiotic properties (Temmerman et al 2003) including antitumoral activity (De Vuyst \& Degeest 1999; Ostile et al 2003), reduction of serum cholesterol (Desmazeaud 1996; Jackson et al 2002), alleviation of lactose intolerance (De Vrese et al 2001), stimulation of the immune system (Isolauri et al 2001) and stabilization of gut microbiota. The LAB are food grade microorganisms and are in generally recognized as safe (GRAS) status that increases their technological potentials in food industry (Trias et al 2008). LAB are widely used in the production of dairy products such as yohurts and fermented milks because of their health benefits. Recently, researches have increased for the isolation of LAB from non-dairy products.

Hardaliye is a lactic acid fermented beverage produced from red grape or grape juice with the addition of crushed mustard seeds, benzoic acid. It is widely produced in the Thrace region of Turkey. Grape microbiota plays the major role in the quality of hardaliye. Hardaliye is a valuable, beneficial traditional beverage that is consumed with pleasure and has been produced for centuries in this region. Hardaliye offers a very nice opportunity for the consumption of grape in cold seasons.

Since consumers demand for more varieties of food products in the marketplace, many indigenous and traditional foods have been industrially produced. Hardaliye is one of the traditional products that have potential to become widespread in the market (Coşkun 2005). Therefore, we aimed to determine technological and functional properties of LAB isolated from hardaliye, as a potential functional product in this study.

\section{Material and Methods}

\subsection{Materials}

Twenty-three hardaliye samples were obtained from different households in Kirklareli province of Turkey and used for the isolation of LAB In this study. LAB strains were also isolated from five hardaliye samples that are produced under laboratory conditions using different grape varieties obtained from Tekirdağ Viticulture Research 
Institute, namely Dingil Kara, Kara Üzüm, Cabernet Sauvignon, Izabella and Siyah Üzüm.

\subsection{Methods}

\subsubsection{Production of hardaliye samples}

Grapes were washed and pressed in oak barrels having a tap at the position $10 \mathrm{~cm}$ above the bottom of the barrel. Then $0.2 \%$ of the crushed raw mustard seed and $0.1 \%$ of benzoic acid were mixed with the grape and the mixture was fermented at room temperature $\left(\sim 22^{\circ} \mathrm{C}\right)$ for 7 days.

\subsubsection{Isolation and identification of $L A B$}

Serial dilutions of the fermented mixtures were prepared using Ringer solution and spreaded onto MRS plates. Then, the plates were incubated in anaerobic conditions at $30 \pm 1{ }^{\circ} \mathrm{C}$ for $72 \mathrm{~h}$ (De Man et al 1960). Isolates were tested in terms of colony morphology, cell morphology, Gram staining, catalase reaction, gas formation from glucose, $\mathrm{NH}_{4}$ production from arginine, growth in different salt concentrations $(2 \%$ or $4 \%)$ and growth at different temperatures $\left(15^{\circ} \mathrm{C}\right.$ or $45^{\circ} \mathrm{C}$ ) (Schillinger \& Lucke 1989). Total 50 isolates were selected and tested in API 50 CHL kits (Bio Merieux, France) to determine the ability to use carbohydrates.

\subsubsection{Genotypic identification of $L A B$}

\subsubsection{Isolation of genomic DNA}

For DNA isolation, bacterial strains were grown overnight in MRS broth at $30^{\circ} \mathrm{C}$. An aliquot of $1 \mathrm{~mL}$ bacterial suspension was centrifuged at $14,000 \mathrm{~g}$ for $20 \mathrm{~min}$ and from each bacterial culture supernatant weight by weighing about $20 \mathrm{mg}$ was obtained from biomass (Pitcher et al 1989). DNA isolation was performed using commercial isolation kit (Quiagen, Taiwan).

\subsubsection{The determination of DNA concentration and preparation of working solution}

The amount of DNA was determined using spectrophotometer (Hitachi U-5100 UV/VIS, Japan) at $260 \mathrm{~nm}$ wavelength. The resulting amount of the genetic material, protein was determined by measurement carried out at $280 \mathrm{~nm}$ (Marmur 1961).

\subsubsection{Genotypic identification of isolates}

16s rRNA gene of the isolates were amplified by following primers: forward primer, 5'-CCGTCAATTCCTTTGAGTTT- 3' and reverse primer, 5'-CCGTCAATTCCTTTGAGTTT- 3' (Beasley \& Saris 2004).

Amplification was achieved by programmable thermal controller, after a pre denaturation step at $94{ }^{\circ} \mathrm{C}$ for $5 \mathrm{~min}$, by the 30 incubation cycles of denaturation at $94{ }^{\circ} \mathrm{C}$ for $45 \mathrm{~s}$, primer annealing at $53{ }^{\circ} \mathrm{C}$ for $1 \mathrm{~min}$, and polymerization at $72{ }^{\circ} \mathrm{C}$ for 1 min. Final DNA extension was performed at $72^{\circ} \mathrm{C}$ for $2 \mathrm{~min}$. Sterile water was used as negative control.

Aliquots of PCR products $(10 \mu \mathrm{L})$ were analyzed by electrophoresis $(30 \mathrm{~min}$ at $100 \mathrm{~V})$ through $1 \%$ $\left(\mathrm{w} \mathrm{v}^{-1}\right)$ agarose gel in tris-acetate buffer (Meyers et al 1976). A $5 \mu \mathrm{L}$ of a $1 \mathrm{~kb}$ DNA ladder marker was used as a size marker. Then amplification products were stained with ethidium bromide and analyzed by gel documentation system.

\subsubsection{Genetic relationship by $B O X-P C R$}

A PCR-reaction mixture $(30 \mu \mathrm{L})$ containing $5 \mu \mathrm{L}$ 5x Gitschier buffer (for $200 \mathrm{~mL}$; $16.6 \mathrm{~mL} 1 \mathrm{M}$ $\left(\mathrm{NH}_{4}\right)_{2} \mathrm{SO}_{4}, 67 \mathrm{~mL} 1 \mathrm{M}$ Tris-HCl $(\mathrm{pH} 8.8), 6.7 \mathrm{~mL}$ $1 \mathrm{M} \mathrm{MgCl}_{2}, 1.3 \mathrm{~mL} \mathrm{0.5} \mathrm{M} \mathrm{EDTA} \mathrm{(pH} \mathrm{8.8)} \mathrm{and} \mathrm{2.08}$ $\mathrm{mL}$ 14.4 M-mercapto-ethanol and was incorporated with $200 \mathrm{~mL}$ of distillated water), $2.5 \mu \mathrm{L}$ DMSO, $1.25 \mu \mathrm{L}$ BSA, $1.25 \mu \mathrm{L}$ dNTP mix, $4 \mu \mathrm{L}$ primer BOX AIR (5' CTA CGG CAA GGC GAC GCT GAC G3'), $0.3 \mu \mathrm{L}$ taq DNA polimerase, $11.7 \mu \mathrm{L}$ sterile distilled water was added to $4 \mu \mathrm{L}$ g-DNA (75 ng $\left.\mu \mathrm{L}^{-1}\right)$ of each sample. PCR cycling conditions were 7 min at $95^{\circ} \mathrm{C}, 30$ cycles of $1 \mathrm{~min}$ at $95^{\circ} \mathrm{C}, 1 \mathrm{~min}$ at $53{ }^{\circ} \mathrm{C}$ and $8 \mathrm{~min}$ at $65^{\circ} \mathrm{C}$ and final step of $15 \mathrm{~min}$ at $65^{\circ} \mathrm{C}$ (Louws et al 1994; Norman et al 2003).

Aliquots of BOX-PCR products $(10 \mu \mathrm{L})$ were analyzed by electrophoresis and visualized as described above. 


\subsubsection{DNA sequence analysis}

LAB isolates isolated from hardaliye were analyzed to determine the structure of DNA. DNA purification of the samples and DNA sequence analysis were made by the company of IONTEK (Istanbul). Formed by the band patterns of each isolate was noted and analyzed using SPSS (Statistical Package for Social Sciences 2009, 18:0 Edition for Windows) and their genetic relationship rate was determined with dendogram. BLAST analysis was conducted according to Altschul et al (1997).

\subsubsection{Determination of technological and functional properties of $L A B$ isolates}

Isolates were inoculated in MRS broth and incubated at $30^{\circ} \mathrm{C}$ to test the acid production capabilities. $\mathrm{pH}$ measurement of cultures were made at the end of $3^{\text {rd }}, 6^{\text {th }}, 18^{\text {th }}$ and $24^{\text {th }} \mathrm{h}$ periods during the incubation (Sağdıç et al 2002).

LAB strains were tested for their ability to produce hydrogen sulphide from Triple Sugar Iron agar (TSI, Oxoid). Sterilized TSI agar plate was inoculated by streaking the slant and incubated at $30{ }^{\circ} \mathrm{C}$ for 2 weeks. The reactions were examined daily for the formation of the blackness in the media (Lee \& Simard 1984). For determination of hydrogen peroxide production capabilities, measurements were conducted at a wavelegth of $360 \mathrm{~nm}$ with a spectrophotometer (Toksoy 1996). The configuration of the lactic acid enantiomers was determined enzymatically using d-lactate and 1-lactate dehydrogenase (Biopharm 2014).

Antibacterial activities were tested against Staphylococcus aureus ATCC 25923, Listeria monocytogenes ATCC 7644, Salmonella enteritidis ATCC 13076, Escherichia coli ATCC 25922 and E. coli O157:H7 NCTC 12900 using agar diffusion method as described for LAB strains using $10^{7} \mathrm{cfu}$ $\mathrm{mL}^{-1}$ concentrations of the tested strains (Toksoy 1996). In order to test bacteriocin and bacteriocinlike substance production capability of the isolates, S. aureus ATCC 25923, L. monocytogenes ATCC 7644, S. enteritidis ATCC 13076, E. coli ATCC
25922, E. coli O157:H7 NCTC 12900 were used (Toksoy 1996).

LAB isolates were subcultured in $10 \mathrm{~mL}$ of fresh MRS broth adjusted to different $\mathrm{pH}$ values (1 and 3) with $\mathrm{HCl}(3 \mathrm{M})$ for the determination of acid tolerance after grown in MRS broth at $37^{\circ} \mathrm{C}$ overnight (Hyronimus et al 2000)

Five antibiotic discs were used to determine the antibiotic resistance of LAB strains. These antibiotic discs were chloramphenicol (CHL), kanamycin (KAN), penicillin G (PEN), streptomycin (STR) and tetracyclin hydrochloride (TET) (Kheadr et al 2007). Results were evaluated according to the criteria of Clinical and Laboratory Standards Institute (CLSI 2012). The sensitivity of the strains to bile salts was determined according to the method described by Vinderola \& Reinheimer (2003). Cell surface hydrophobicity was determined by the method of Perez et al (1998).

\section{Results and Discussion}

\subsection{Phenotypic properties of LAB isolates}

It was detected that as 28 isolates grown at 45 ${ }^{\circ} \mathrm{C}$ produced gas from glucose whereas no gas production was detected for 73 isolates grown at 15 ${ }^{\circ} \mathrm{C}$. All isolates showed growth in $2 \% \mathrm{NaCl}$, except sample one. However, no growth was observed in $4 \% \mathrm{NaCl}$. Thirty isolates were able to produce $\mathrm{NH}_{4}$ from arginine.

\subsection{Carbohydrate metabolism (API $50 \mathrm{CHL}$ ), identification of $L A B$ isolates}

Phenotypic properties of Lactobacillus isolates, which were identified, were selected and API 50 CHL test was performed. According to API 50 CHL test, it was identified that 23 isolates $(46 \%)$ were Lactobacillus plantarum, 20 isolates (40\%) were Lactobacillus pentosus, 4 isolates (8\%) were Lactobacillus brevis and the remaining 3 isolates (6\%) were Lactobacillus collinoides.

As a result of API 50, 23 isolates (HR2, HR6, HR9, HR13, HR21, HR27, HR29, HR30, HR34, HR35, HR42, HR43, HR48, HR49, HR51, HR54, 
HR60, HR64, HR77, HR88, HR91, HR93, HR96) were identified as Lactobacillus plantarum, 22 of the isolates (HR10, HR14, HR31, HR33, HR36, HR37, HR38, HR39, HR50, HR56, HR57, HR59, HR62, HR75, HR84, HR86, HR89, HR92, HR94, HR97) were identified as Lactobacillus pentosus, 4 of the isolates (HR1, HR22, HR26, HR40) were identified as Lactobacillus brevis and 3 of the isolates (HR88, HR90, HR95) identified as Lactobacillus collinoides.

\subsection{Genotypic identification of isolates}

Species of all the strains were identified based on the DNA sequence analysis results. In the results, 26 isolates (HR1, HR2, HR6, HR9, HR13, HR22, HR27, HR29, HR34, HR35, HR37, HR40, HR42, HR43, HR49, HR51, HR54, HR57, HR59, HR60, HR64, HR85, HR86, HR89, HR93, HR97) were identified as Lactobacillus plantarum with similarity indices from 92 to $99 \%, 17$ of the isolates (HR10, HR26, HR31, HR33, HR36, HR38, HR39, HR62, HR75, HR84, HR88, HR90, HR91, HR92, HR94, HR95, HR96) were identified as Lactobacillus brevis with similarity indices from 90 to $99 \%$, one isolate (HR50) were not identified. Identification results according to API50 and $16 \mathrm{~S}$ riposomal RNA gene sequencing using NCBI BLASTn (Basic Local Alignment. Search Tool nucleotide).

16S riposomal RNA gene sequencing and BLAST search showed that twenty four isolates were identified as Lactobacillus plantarum NC_004567.2 (HR1, HR2, HR6, HR9, HR13, HR22, HR27, HR29, HR35, HR37, HR40, HR42, HR43, HR49, HR51, HR54, HR57, HR59, HR60, HR64, HR85, HR86, HR93, HR97), one isolate identified as L. plantarum AY 590777 (HR34), one isolated identified as $L$. plantarum CP012122.1 (HR89), fifteen isolates identified as L. brevis NC_008497.1 (HR10, HR26, HR31, HR36, HR38, HR39, HR62, HR84, HR88, HR90, HR91, HR92, HR94, HR95, HR96) and two L. brevis LC 062897.1 (HR33, HR75).

These findings supported the aim, which was the determination of the main LAB strains playing roles in hardaliye fermentation in which low numbers of hardaliye investigated in our study can also be explained with this aim.

\subsubsection{Genetic relationship among LAB strains}

BOX-PCR genotypic characterization of the isolates from occurring polymorphisms has been utilized. As shown in Figure 1, all strains generated bands of 2500 with BOX-PCR. Some of them, however, exhibited additional bands with sizes of $1000 \mathrm{bp}$ (14 strains), $1200 \mathrm{bp}$ (8 strains), $1700 \mathrm{bp}$ (5 strains), 500 bp (2 strains) or 2000 bp (only one strain). BOX-PCR profiles of the strains generated two main clusters. The similarity level among strains determined with BOX-PCR was found as 98\% (Figure 2).

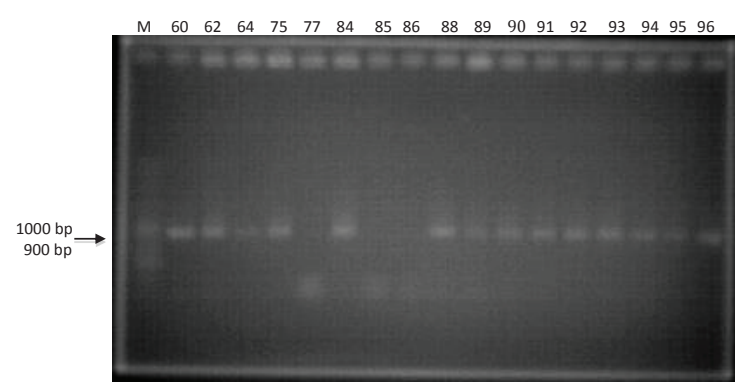

Figure 1- PCR amplification with 16S rRNA genes

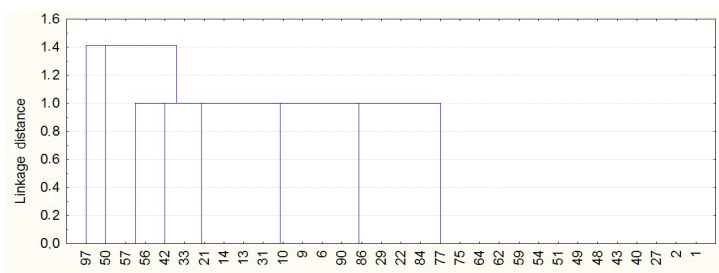

Figure 2- Cluster analysis of BOX-PCR

\subsection{Technological and probiotic properties of $L A B$ isolates}

To test acid production ability, the isolates were inoculated one by one to tubes containing MRS broth and incubated at $30 \pm 1{ }^{\circ} \mathrm{C}$. pH was measured at the end of $3^{\text {rd }}, 6^{\text {th }}, 18^{\text {th }}$ and $24^{\text {th }}$ hours of incubation period. $\mathrm{pH}$ of medium changed between 3.91 and 4.56 at the end of the incubation $(24 \mathrm{~h})$. Lactic acid production level of the isolates was found to be between 0.949 and $3.901 \mathrm{~g} \mathrm{~L}^{-1}$ at the end of the incubation period. None of the isolates tested produced hydrogen sulfide. Hydrogen peroxide 
$\left(\mathrm{H}_{2} \mathrm{O}_{2}\right)$ produced by isolates changed between 1.57$3.75 \mu \mathrm{g} \mathrm{mL} \mathrm{m}^{-1}$. Only one strain produced L-lactate while the other isolates produced DL-lactate or D-lactate. Total lactic acid production of LAB isolates after $24 \mathrm{~h}$ was determined between 0.949 and $3.901 \mathrm{~g} \mathrm{~L}^{-1}$.

Effects of LAB isolates on different pathogens are shown in Table 1. In general, the isolates showed the highest antibacterial effect on $S$. aureus while effect on L. monocytogenes and E. coli O157:H7 was generally lower than those of others. All isolates except HR27 showed inhibitory effects on the tested bacteria (Table 1).

None of the isolates produced a visible inhibition zone. Therefore, it was found that LAB isolates did not produce bacteriocin or bacteriocin-like substances.

Table 1- Antibacterial activity of LAB isolates (Zone diameter; mm)

\begin{tabular}{|c|c|c|c|c|c|c|c|c|c|c|c|}
\hline 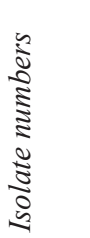 & $\begin{array}{c}\tilde{y} \\
\tilde{\Xi} \\
\vdots \\
\vdots \\
\dot{0} \\
\dot{0}\end{array}$ & 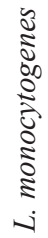 & 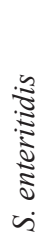 & $\begin{array}{l}\underset{0}{0} \\
\dot{0}\end{array}$ & 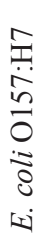 & 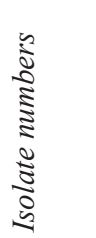 & 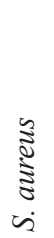 & 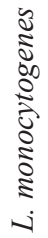 & 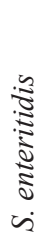 & $\begin{array}{l}\stackrel{\tilde{0}}{0} \\
1\end{array}$ & 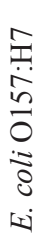 \\
\hline HR1 & 28 & 9 & 13 & 15 & 6 & HR49 & 24 & 8 & 9 & 9 & 7 \\
\hline HR2 & 25 & 11 & 13 & 13 & 7 & HR50 & 26 & 8 & 7 & 8 & 8 \\
\hline HR6 & 23 & 10 & 13 & 12 & 6 & HR51 & 27 & 7 & 4 & 9 & 8 \\
\hline HR9 & 24 & 9 & 12 & 14 & 8 & HR54 & 26 & 8 & 5 & 10 & 8 \\
\hline HR10 & 23 & 8 & 11 & 12 & 7 & HR56 & 34 & 9 & 18 & 15 & 14 \\
\hline HR13 & 24 & 8 & 12 & 12 & 8 & HR57 & 29 & 5 & 11 & 13 & 11 \\
\hline HR14 & 27 & 9 & 12 & 11 & 9 & HR59 & 28 & 7 & 13 & 13 & 10 \\
\hline HR21 & 25 & 9 & 11 & 10 & 10 & HR60 & 26 & 8 & 12 & 12 & 12 \\
\hline HR22 & 30 & 7 & 9 & 10 & 11 & HR62 & 27 & 6 & 12 & 11 & 7 \\
\hline HR26 & 28 & 8 & 9 & 11 & 8 & HR64 & 29 & 8 & 13 & 13 & 12 \\
\hline HR27 & 26 & 8 & 10 & 11 & - & HR75 & 29 & 8 & 13 & 12 & 11 \\
\hline HR29 & 26 & 9 & 11 & 11 & 10 & HR77 & 28 & 6 & 15 & 12 & 11 \\
\hline HR30 & 24 & 9 & 10 & 10 & 9 & HR84 & 29 & 7 & 13 & 13 & 11 \\
\hline HR31 & 25 & 8 & 8 & 10 & 9 & HR85 & 29 & 8 & 11 & 13 & 13 \\
\hline HR33 & 32 & 9 & 10 & 9 & 9 & HR86 & 26 & 8 & 10 & 11 & 9 \\
\hline HR34 & 27 & 8 & 11 & 9 & 8 & HR88 & 25 & 6 & 9 & 12 & 9 \\
\hline HR35 & 29 & 8 & 10 & 10 & 9 & HR89 & 28 & - & 11 & 14 & 7 \\
\hline HR36 & 29 & 6 & 11 & 10 & 8 & HR90 & 30 & 9 & 13 & 12 & 8 \\
\hline HR37 & 31 & 8 & 9 & 9 & 7 & HR91 & 26 & 8 & 11 & 9 & 4 \\
\hline HR38 & 26 & 9 & 6 & 9 & 6 & HR92 & 27 & 8 & 5 & 8 & 7 \\
\hline HR39 & 28 & 11 & 7 & 11 & 8 & HR93 & 26 & 6 & 3 & 59 & 7 \\
\hline HR40 & 28 & 9 & 7 & 12 & 9 & HR94 & 25 & 7 & 5 & 11 & 7 \\
\hline HR42 & 26 & 5 & 8 & 12 & 8 & HR95 & 25 & 6 & 5 & 9 & 5 \\
\hline HR43 & 26 & 8 & 7 & 7 & 7 & HR96 & 24 & 7 & 5 & 6 & 4 \\
\hline HR48 & 26 & 8 & 7 & 10 & 8 & HR97 & 25 & 9 & 12 & 12 & 8 \\
\hline
\end{tabular}

S. aureus, ATCC 25923; L. monocytogenes, ATCC 7644; S. enteritidis, ATCC 13076; E. Coli, ATCC 25922; E. Coli O157:H7, NCTC 12900 
Tolerances of the isolates against acidity were investigated in two different $\mathrm{pH}$ values $(\mathrm{pH} 1$ and 3). None of the isolates could maintain their viability at $\mathrm{pH} 1$ at the end of $180 \mathrm{~min}$ incubation while viability rate of the isolates changed between 37.39 and $90 \%$ at $\mathrm{pH} 3$.

The viability of LAB strains isolated from different hardaliye samples was substantially influenced from tetracyclin hydrocloride, chloramphenicol and penicillin. Antibiotic resistance of the isolates is presented in the Table 2. As can be seen, $18 \%$ of the isolates showed resistance against tetracyclin hydrocloride. $78 \%$ of the isolates intermediate susceptible, $6 \%$ of the isolates susceptible against tetracyclin hydrocloride. None of the isolates showed resistance against chloramphenicol. $10 \%$ of the isolates intermediate susceptible, $90 \%$ of the isolates susceptible against chloramphenicol. $38 \%$ of the isolates showed resistance against penicillin. $38 \%$ of the isolates intermediate susceptible, $24 \%$ of the isolates susceptible against penicillin. All isolates resistance against kanamycin and streptomycin.

Isolates showed moderate tolerance to bile salts at $0.3 \%$ concentration. The isolates grew slowly in medium containing $0.5 \%$ and $1 \%$ bile salts while six isolates were not be able to grow in medium with $1 \%$ bile salts.

It is clear from the results that in spite of low levels, all isolates except for HR 6 had hydrophobicity

Table 2- Antibiotic resistances of $\mathrm{LAB}$ isolates

\begin{tabular}{|c|c|c|c|c|c|c|c|c|c|c|c|}
\hline Isolate numbers & TET & CHL & PEN & $K A N$ & STR & Isolate numbers & TET & CHL & PEN & $K A N$ & STR \\
\hline HR1 & $\mathrm{I}$ & $\mathrm{S}$ & $\mathrm{S}$ & $\mathrm{R}$ & $\mathrm{R}$ & HR49 & $\mathrm{I}$ & $\mathrm{S}$ & I & $\mathrm{R}$ & $\mathrm{R}$ \\
\hline HR2 & I & S & S & $\mathrm{R}$ & $\mathrm{R}$ & HR50 & I & S & S & $\mathrm{R}$ & $\mathrm{R}$ \\
\hline HR6 & I & S & I & $\mathrm{R}$ & $\mathrm{R}$ & HR51 & I & S & $\mathrm{R}$ & $\mathrm{R}$ & $\mathrm{R}$ \\
\hline HR9 & I & I & I & $\mathrm{R}$ & $\mathrm{R}$ & HR54 & I & S & S & $\mathrm{R}$ & $\mathrm{R}$ \\
\hline HR10 & I & I & I & $\mathrm{R}$ & $\mathrm{R}$ & HR56 & I & S & $\mathrm{R}$ & $\mathrm{R}$ & $\mathrm{R}$ \\
\hline HR13 & I & S & I & $\mathrm{R}$ & $\mathrm{R}$ & HR57 & I & S & $\mathrm{R}$ & $\mathrm{R}$ & $\mathrm{R}$ \\
\hline HR14 & I & S & $\mathrm{S}$ & $\mathrm{R}$ & $\mathrm{R}$ & HR59 & I & $\mathrm{S}$ & I & $\mathrm{R}$ & $\mathrm{R}$ \\
\hline HR21 & $\mathrm{R}$ & S & I & $\mathrm{R}$ & $\mathrm{R}$ & HR60 & I & S & I & $\mathrm{R}$ & $\mathrm{R}$ \\
\hline HR22 & I & S & S & $\mathrm{R}$ & $\mathrm{R}$ & HR62 & I & S & $\mathrm{R}$ & $\mathrm{R}$ & $\mathrm{R}$ \\
\hline HR26 & I & $\mathrm{S}$ & I & $\mathrm{R}$ & $\mathrm{R}$ & HR64 & I & S & I & $\mathrm{R}$ & $\mathrm{R}$ \\
\hline HR27 & $\mathrm{R}$ & S & $\mathrm{R}$ & $\mathrm{R}$ & $\mathrm{R}$ & HR75 & $\mathrm{S}$ & S & $\mathrm{R}$ & $\mathrm{R}$ & $\mathrm{R}$ \\
\hline HR29 & $\mathrm{R}$ & S & $\mathrm{R}$ & $\mathrm{R}$ & $\mathrm{R}$ & HR77 & I & S & S & $\mathrm{R}$ & $\mathrm{R}$ \\
\hline HR30 & I & S & $\mathrm{R}$ & $\mathrm{R}$ & $\mathrm{R}$ & HR84 & I & S & S & $\mathrm{R}$ & $\mathrm{R}$ \\
\hline HR31 & I & S & $\mathrm{R}$ & $\mathrm{R}$ & $\mathrm{R}$ & HR85 & I & S & I & $\mathrm{R}$ & $\mathrm{R}$ \\
\hline HR33 & $\mathrm{R}$ & I & $\mathrm{R}$ & $\mathrm{R}$ & $\mathrm{R}$ & HR86 & I & $\mathrm{S}$ & S & $\mathrm{R}$ & $\mathrm{R}$ \\
\hline HR34 & $\mathrm{R}$ & S & I & $\mathrm{R}$ & $\mathrm{R}$ & HR88 & I & S & $\mathrm{R}$ & $\mathrm{R}$ & $\mathrm{R}$ \\
\hline HR35 & I & I & I & $\mathrm{R}$ & $\mathrm{R}$ & HR89 & I & S & $\mathrm{R}$ & $\mathrm{R}$ & $\mathrm{R}$ \\
\hline HR36 & I & $\mathrm{S}$ & I & $\mathrm{R}$ & $\mathrm{R}$ & HR90 & I & $\mathrm{S}$ & $\mathrm{S}$ & $\mathrm{R}$ & $\mathrm{R}$ \\
\hline HR37 & I & $\mathrm{S}$ & S & $\mathrm{R}$ & $\mathrm{R}$ & HR91 & I & $\mathrm{S}$ & $\mathrm{R}$ & $\mathrm{R}$ & $\mathrm{R}$ \\
\hline HR38 & $\mathrm{R}$ & S & I & $\mathrm{R}$ & $\mathrm{R}$ & HR92 & I & $\mathrm{S}$ & $\mathrm{R}$ & $\mathrm{R}$ & $\mathrm{R}$ \\
\hline HR39 & S & $\mathrm{S}$ & $\mathrm{S}$ & $\mathrm{R}$ & $\mathrm{R}$ & HR93 & I & $\mathrm{S}$ & $\mathrm{R}$ & $\mathrm{R}$ & $\mathrm{R}$ \\
\hline HR40 & I & $\mathrm{S}$ & I & $\mathrm{R}$ & $\mathrm{R}$ & HR94 & $\mathrm{S}$ & $\mathrm{S}$ & $\mathrm{R}$ & $\mathrm{R}$ & $\mathrm{R}$ \\
\hline HR42 & I & $\mathrm{S}$ & $\mathrm{R}$ & $\mathrm{R}$ & $\mathrm{R}$ & HR95 & $\mathrm{R}$ & $\mathrm{S}$ & I & $\mathrm{R}$ & $\mathrm{R}$ \\
\hline HR43 & $\mathrm{R}$ & I & I & $\mathrm{R}$ & $\mathrm{R}$ & HR96 & I & $\mathrm{S}$ & $\mathrm{R}$ & $\mathrm{R}$ & $\mathrm{R}$ \\
\hline HR48 & $\mathrm{R}$ & $\mathrm{S}$ & I & $\mathrm{R}$ & $\mathrm{R}$ & HR97 & I & $\mathrm{S}$ & $\mathrm{R}$ & $\mathrm{R}$ & $\mathrm{R}$ \\
\hline
\end{tabular}

TET, tetracyclin hydrocloride (30 $\mu \mathrm{g})$; CHL, chloramphenicol (30 $\mu \mathrm{g})$; PEN, penicillin (10 U); KAN, kanamycin (30 $\mu \mathrm{g})$; STR, streptomycin $(10 \mu \mathrm{g})$ (Bioanalyse) 
against xylene. Hydrophobicity value of the isolates changed between 1.01 and $15.82 \%$ suggesting some strains might adhere better than the others to the gastrointestinal tract, which is a crucial functional characteristic in probiotic action.

Lactic acid-producing ability of the isolates was partly similar to those reported by Arici et al (2004).

Hydrogen sulfide production capability of LAB isolates was not in accordance with those reported by Lee \& Simard (1984) and Arici et al (2004). These studies showed that some LAB did not generate hydrogen sulfide and hydrogen sulfide production depends on the sulfite reductase and cysteine desulfohydrase enzyme activity of LAB strains (Fernandes et al 1987).

Toksoy et al (1999) found the $\mathrm{H}_{2} \mathrm{O}_{2}$ production ranged between $1.80-3.45 \mu \mathrm{g} \mathrm{mL}^{-1}$ while Raccach \& Baker (1978) found as $0.85 \mu \mathrm{g} \mathrm{mL}^{-1}$. In another study, it was concluded that L. plantarum isolates produced 0.59-0.65 $\mu \mathrm{g} \mathrm{mL} \mathrm{mL}^{-1}$ hydrogen peroxide (Beyatlı \& Akbari 1996). In this research, hydrogen peroxide production of the isolates was similar to findings of Toksoy et al (1999) and higher than those of Raccach \& Baker (1978) and Beyatl \& Akbari (1996), respectively. LAB produced different amounts of hydrogen peroxide, which can be related with their different oxygen oxidoreductase activities (Reinheimer et al 1990).

D- and L-lactate production capabilities of LAB isolates in our study were in accordance with those of Arici et al (2004).

Arici et al (2004) determined that LAB ( $L$. rhamnosus, $L$. paracasei subsp. paracasei, $L$. fermentum, L. buchneri, L. brevis, L. curvatus and Lactobacillus sp.) isolated from the faeces of baby formed inhibition zone against most pathogenic bacteria (E. coli ATCC 25922, S. aureus ATCC 2392, S. aureus ATCC 28213). Aslim \& Beyatlı (2000) investigated inhibition effect of $S$. thermophilus and L. bulgaricus by 5 units from yohurt starter cultures on two different E. coli (I and II) and S. aureus (I and II). Generally all the starter strains showed the highest effect on S. aureus II. Toksoy et al (1999) investigated the inhibition effect of 39 different $L$. plantarum isolates isolated from sucuks and sausages on $E$. coli
K12, coagulase positive $S$. aureus 4-43 and mutant coagulase negative $S$. aureus. Two strains did not show inhibitory effect on $E$. coli, while others resulted in different inhibitory effect level. Four strains did not show inhibitory effect on $S$. aureus positive. Tambekar \& Bhudata (2010) investigated antimicrobial effect of Lactobacillus strains perceived as leading probiotics among 48 Lactobacillus strains isolated from goat milk on E. coli (MTCC443), Enterobacter aerogenes (MTCC 111), Klebsiella pneumoniae (MTCC 2653), Proteus vulgaris (MTCC 426), Salmonella typhi (MTCC 734) and Shigella flexneri (MTCC 1457). LAB showed different inhibitory effects on the tested bacteria.

Acid tolerances of the LAB isolates were similar to those determined by Iñiguez-Palomares et al (2007).

Antibiotic resistances of $\mathrm{LAB}$ isolates were consistence with results isolated Arici et al (2004) in which LAB strains isolated from the faeces of baby were found to be resistant against kanamycin and streptomycin, whereas they were sensitive against amoxycillin, chloramphenicol, erythromycin, penicillin and tetracyclin. Xanthopoulos et al (2000) isolated Lactobacillus paracasei subsp. paracasei, $L b$. rhamnosus, Lb. acidophilus, Lb. gasseri and $L b$. reuteri from the faeces of baby (new born) and they detected that these isolates were sensitive against chloramphenicol, erythromycin, penicillin $G$ and tetracycline. Tambekar \& Bhudata (2010) reported that probiotic strains of L. plantarum (G95a and G96a) and L. rhamnosus (G119b) isolated from goat milk were resistant to tetracycline while L. rhamnosus (G92 and G99c) was sensitive to tetracycline. Resistance of the probiotic strains to some antibiotics could be used for both preventive and therapeutic purposes in controlling intestinal infections although presence of the antibiotic resistance genes in these strains can also be problem in some aspects. Their resistance to antibiotics clarifies their potential in minimizing the negative effects of antibiotic therapy on the host bacterial ecosystem should be considered (El-Naggar 2004).

Raibaud (1992) reported that even low concentrations of bile salts (in vitro) were able to inhibit the microorganisms. Gilliland et al (1984) 
claimed that bile salt at $0.3 \%$ concentration was decisive on the determination of resistance of microorganisms against these salts.

Hydrophobicity capability of the LAB isolates was in accordance with that of Mishra \& Prasad (2005) who examined hydrophobicity ability of Lactobacillus casei strains and found that xylene hydrophobicity was between $5.81 \%$ and $42.52 \%$.

\section{Conclusions}

All of the LAB strains isolated from hardaliye samples belonged to genus Lactobacillus and Lactobacillus plantarum was the dominant species in the microbiota. Around $98 \%$ of the isolates were similar to each other, indicating that, diversity of the starter LAB during the fermentation was very low. The isolates were found to have potentials to be used as starter cultures in the production of hardaliye due to their technological and functional properties. The antimicrobial effects and acid production capabilities of the isolates support this idea. The largest gain of our study was the determination of effective LAB during the fermentation of hardaliye and revealing their technological and functional properties.

\section{Acknowledgements}

The authors gratefully acknowledged the TUBITAK (Project number: 1100018) for providing funding for this work.

\section{References}

Altschul S F, Madden T L, Schaffer A A, Zhang J Z Z, Miller W \& Lipman D J (1997). Gapped Blast and Psi-Blast: A new generation of protein database search programs, pp. 3389-3402

Arici M, Bilgin B, Sagdic O \& Ozdemir C (2004). Some characteristics of Lactobacillus isolates from infant faeces. Food Microbiology 21: 19-24

Aslım B \& Beyatlı Y (2000). Yoğurt starter kültür metabolitlerinin inhibisyon etkisi. Turkish Journal of Biology 24: 65-78

Battock M \& Azam-Ali S (1998). Fermented Fruits and Vegetables. A Global Perspective. FAO Agricultural Services Bulletin No. 134. M-17
Beyatlı Y \& Akbari M(1996). UV-1şınlarının Lactobacillus plantarum ve Pediococcus pentosaceus bakterileri üzerine etkisinin araştırılması. Gazi University Journal of Science 9: 255-262

Biopharm (2014). UV-method for the determination of $\mathrm{d}$ - and 1-lactic acid in foodstuffs and other materials. http:/www.r-biopharm.com/wp-content/ uploads/4076/MSDS-11112821035-D-lactic-Llactic-acid-test-kit_1.4_EN.pdf (Erişim tarihi: 15.12.2013)

CLSI (2012). Clinical and Laboratory Standards Institute. Performance Standards for Antimicrobial Disk Susceptibility Tests; Approved Standard-Eleventh Edition M02-A11 Vol: 32, No: 1 Replaces M02-A10, Vol: 29, No: 1

Coşkun F (2005). Geleneksel fermente bir içeceğimiz hardaliye. Hasad Gida 21: 22-25

De Man J C, Rogosa M \& Sharpe M E (1960). A medium for the cultivation of lactobacilli. Journal of Applied Bacteriology 23: 130-135

Desmazeaud M (1996). Les bactéries lactiques dans l'alimentation humaine: Utilisation et innocuité. Cahiers Agricultures 5: 331-343

De Vrese M, Steglman A, Richter B, Fenselau S, Laue C \& Scherezenmeir J (2001). Probiotics-compensation for lactase insufficiency. American Journal of Clinical Nutrition 73: 421-429

De Vuyst L \& Degeest B (1999). Heteropolysaccharides from lactic acid bacteria. FEMS Microbilogy Reviews 23: $153-177$

El-Naggar M Y M (2004). Comparative study of probiotic cultures to control the growth of Escherichia coli O157:H7 and Salmonella typhimurium. Asian Network for Scientific Information Biotechnology 3: 173-180

Fernandes C F, Shahani K M \& Amer M A (1987). Therapeutic role of dietary lactobacilli and lactobacillic fermented in dairy products. FEMS Microbiology Reviews 46: 343-356

Gilliland S E, Staley T E \& Bush L J (1984). Importance of bile tolerance of Lactobacillus acidophilus used as dietary adjunct. Journal of Dairy Science 67: 30453051

Hyronimus B, Le Marrec C, Hadj Sassi A \& Deschamp A (2000). Acid and bile tolerance of spore-forming lactic acid bacteria. International Journal of Food Microbiology 61: 193-197

Iñiguez-Palomares C, Pérez-Morales R \& Acedo-Félix E (2007). Evaluation of probiotic properties in 
Lactobacillus isolated from small intestine of piglets. Revista Latinoamericana de Microbiología 49: 46-54

Isolauri E, Sütäs Y, Kankaapää P, Arvilommi H \& Salminen S (2001). Probiotics: Effects of immunity. The American Journal of Clinical Nutrition 73: 444450

Jackson M S, Bird A R \& McOrist A I (2002). Comparison of two selective media for the detection and enumeration of lactobacilli in human faeces. Journal of Microbiological Methods 51: 313-321

Kheadr E, Dabour N, Le Lay C, Lacroix C \& Fliss I (2007). Antibiotic susceptibility profile of bifidobacteria as affected by oxgall, acid, and hydrogen peroxide stress. Antimicrobial Agents Chemotherapy 51: 169-174

Lee B H \& Simard R E (1984). Evaluation methods for detecting the production of $\mathrm{H}_{2} \mathrm{~S}$, volatile sulfides, and greening by Lactobacilli. Journal of Food Science 49: 981-983

Louws F J, Fulbright D W, Stephens C T \& de Bruijn F J (1994). Specific genomic fingerprints of phytopathogenic Xanthomonas and Pseudomonas pathovars and strains generated with repetitive sequences and PCR. Applied and Environmental Microbiology 60: 2286-2295

Marmur J (1961). A procedure for the isolation of deoxyribonucleic acids. Journal of Molecular Biology 3: $585-594$

Meyers J A, Sanchez D, Elwell L P \& Falkow S (1976). Simple agarose gel electrophoretic method for the identification and characterization of plasmid deoxyribonucleic acid. Journal of Bacteriology 127: 1529-1537

Mishra V \& Prasad D N (2005). Application of in vitro methods for selection of Lactobacillus casei strains as potential probiotics. International Journal of Food Microbiology 103: 109-115

Norman D J, Yuen J M F, Resendiz R \& Boswell J (2003). Characterization of Erwinia populations from nursery retention ponds and lakes infected ornamental plants in Florida. Plant Disease 87: 193-196

Ostile H M, Helland M H \& Narvhus J A (2003). Growth and metabolism of selected strains of probiotic bacteria in milk. International Journal of Food Microbiology 87: 17-27

Perez P F, Minnaard Y, Disalvo E A \& de Antoni G (1998). Surface properties of bifidobacterial strains of human origin. Applied and Environmental Microbiology 64: $21-26$
Pitcher D G, Saunders N A \& Owen R J (1989). Rapid extraction of bacterial genomic DNA with guanidium thiocyanate. Letters in Applied Microbiology 8: 151-156

Raccach M \& Baker R C (1978). Formation of hydrogen peroxide by meat starter cultures. Journal of Food Protection 41: 798-799

Raibaud P (1992). Bacterial interactions in the gut. In: R Fuller (ed), Probiotics: The Scientific Basis. Chapman and Hall, London, pp. 9-28

Reinheimer J A, Dekow M R \& Candioti M C (1990). Inhibition of coliform bacteria by lactic cultures. Australian Journal of Dairy Technology 2: 5-9

Sağdıç O, Arici M \& Simşek O (2002). Selection of starters for a traditional Turkish yayik butter made from yoghurt. Food Microbiology 19: 303-312

Schillinger U \& Lucke F K (1989). Antibacterial activity of Lactobacillus sake isolated from meat. Applied and Environmental Microbiology 55: 1901-1906

Tambekar D H \& Bhutada S A (2010). Acid and bile tolerance, antibacterial activity, antibiotic resistance and bacteriocins activity of probiotic Lactobacillus species. Recent Research in Science and Technology 2: 94-98

Temmerman R, Pot B, Huys G \& Swings J (2003). Identification and antibiotic susceptibility of bacterial isolates from probiotic products. International Journal of Food Microbiology 81: 1-10

Toksoy A (1996). A study of some metabolic and antimicrobial activities of Lactobacillus plantarum and Pediococcus pentosaceus strains. PhD Thesis. Gazi University Institute of Science and Technology (Unpublished), Ankara

Toksoy A, Beyatlı Y \& Aslim B (1999). Studing on metabolic and antimicrobial activities of some $L$. plantarum strains isolated from sausages. Turkish Journal of Veterinary and Animal Science 23: 533-540

Trias R, Baneras L, Badosa E \& Montesinos E (2008). Bioprotection of golden delicious apples and iceberg lettuce against foodborne bacterial pathogens by lactic acid bacteria. International Journal of Food Microbiology 123: 50-60

Xanthopoulos V, Litopoulou-Tzanetaki E \& Tzanetakis N (2000). Characterization of Lactobacillus isolates from infant faeces as dietary adjuncts. Food Microbiology 17: 205-215

Vinderola C G \& Reinheimer J A (2003). Lactic acid starter and probiotic bacteria: A comparative "in vitro" study of probiotic characteristics and biological barrier resistance. Food Research International 36: 895-904 